\title{
ANALYSIS OF SOYBEAN PRODUCTION AND BIOGAS YIELD TO IMPROVE ECO-MARKETING AND CIRCULAR ECONOMY
}

Tijana Milanović, Vera Popovićn , Savo Vučković3 , Nikola Rakaščan ${ }^{4}$, Slobodan Popovićs, Zdravka Petković ${ }^{6}$

*Corresponding authorE-mail:vera.popovic@igvcns.ns.ac.rs; bravera@eunet.rs

\begin{abstract}
A R T I C LE I N F O
A B S T R A C T

Original Article

Received: 19 January 2020

In the study attempts to analyze soybean production and possibility obtaining biogas from soybean biomass, in order to obtain energy inputs into the profit function and realized

Accepted: 02 February 2020

doi:10.5937/ekoPolj2001141M

UDC 635.655:338.12 a circular economy. This paper presents the results of fiveyear studies of soybean production analysis in the world and in Serbia, and was also examined soybeans morphoproductive characteristics and on the biogas yield, of the

\section{Keywords:}

soybean production, trade, biomass yield, biogas yield, correlations, circular economy

JEL: J01, L21, O13 Favorit variety, produced in Pancevo, Serbia. Serbia has excellent conditions for soybeans production. The maximum soybean biomass yield of soybean variety Favorit was $5 \mathrm{t}$ ha-1. The average biogas yield, for tested five years, was $368 \mathrm{~m} 3 \mathrm{ha}-1$. The biogas yield was in positive statistically significant correlations on the plant height $\left(\mathrm{r}=0.65^{*}\right)$ and in positive correlations with biomass yield. Soybean cultivar with their characteristics justify the sowing and can be used as a raw material in bio-fuels production.
\end{abstract}

(C) 2020 EA. All rights reserved.

1 Tijana Milanović, PhD student, University of Belgrade, FON - Faculty of Organisational Sciences, Jove Ilića 154, 11010 Belgrade, Serbia, Phone: +381 638480 700, tijana. milanovic@bpa.edu.rs, ORCID ID https://orcid.org/0000-0001-6735-9091

2 Vera Popović, PhD, Institute of Filed and Vegetable Crops, Maxim Gorky 30, 21000 Novi Sad, Serbia, Phone: +381 648205 733, vera.popovic@ifvens.ns.ac.rs, ORCID ID: https:// qa.orcid.org/0000-0001-6032-6457

3 Savo Vučković, PhD, University of Belgrade, Faculty of Agriculture, Nemanjina 6, 11080 Zemun-Belgrade, Serbia, Phone: +381 114413 5550, savovuck@agrif.bg.rc.rs, https:// orcid.org/0000-0002-8027-7784

4 Nikola Rakašćan, PhD student, Biogas Energy, Ilandza, E-mail: n.rakascan@biogasenergy. rs, ORCID ID https://orcid.org/0000-0001-6976-4891

5 Slobodan Popović, PhD, University of Novi Sad, Faculty of Economics and Engineering Management, Cvecarska 2, Novi Sad, Serbia, Phone: +381 640483 563, slobodan. popovic49@gmai.com, ORCID ID https://qa.orcid.org/0000-0002-7884-2051

6 Zdravka Petković, PhD, Academy of Business Professional Studies, 11000 Belgrade, Serbia, Phone: +38163 219230, petzdravka@gmail.com, ORCID ID: https://orcid.org/0000-00025607-387X 


\section{Introduction}

Soybeans are of great economic importance due to the high nutritional, energy and vitamin value of grain used in human, domestic and farmed animal nutrition, as well as in various branches of industrial processing. Harvesting residues have high energy value and are increasingly used as a renewable energy source. The simplest way is by combustion in boiler plants. To produce liquid biofuels in some countries, they use grain (oil) as well as used oil from large food chains (Jankovic et al., 2017). About 200 million tonnes of soybean meal are produced worldwide, or about $63 \%$ of the total amount of all oil plants (Jankovic et al., 2019; Popović et al. 2018a; 2019). The largest soybean selection house in Serbia is the Institute of Field and Vegetable Crops. Soybean producers have at their disposal a wide variety of native NS soybean varieties; highyield varieties of quality grain; varieties that are not genetically modified (Popovic, 2010; Popović et al., 2012a, 2012b, 2013a; b, 2015; 2016; 2019; Stevanovic et al., 2017; Lakic et al., 2018).

Management in agricultural activity must be considered with a particular degree of attention, in which many authors point out in their work (Popović et al., 2018b, Novaković et al., 2018; Radović et al., 2019). Management and specific management are of particular importance in the conditions governing agricultural production, where essentially all factors of production come to terms such as soil, field crops, machinery, labor (Kolarić et al., 2014; Živanović \& Popović, 2016; Živanović et al., 2017; Maksimović et al., 2018; Lakić et al., 2018; Terzić et al., 2018; 2019; Rajičić et al., 2019; Bojović at al., 2019). Eco marketing or green marketing emphasizes management according with environmental protection. Eco marketing promotes the products and technologies that they are in accordance with the concept of sustainable development. Eco marketing will play a crucial role in the coming years in many ways: by its influence on companies to tailor their production and business as a whole in a more sustainable way, and on conveying consumer concerns into concrete work - the purchase of environmentally friendly products.

The European Commission has set a long-term goal to develop a competitive, resource efficient and low carbon economy by 2050. Bio-economy is expected to play an important role in the low carbon economy. We estimate that the current bio economy market is about $€ 2.4$ billion, including agriculture, food and beverage, agroindustrial products, fisherines, forestry, wood-based industry, biochemical, enzymes, biopharmaceutical, biofuls and bioenergy, uses about 2 billion tonnes and employing 22 million persons. New sectors are emerging, such as biomaterials and green chemistry. The transition toward a bio-economy will rely on the advancement in technology of a range of processes, on the achievement of a breakthrough in terms of technical performances and cost effectiveness and will depend on the availability of sustainable biomass (Scarlat et al., 2015).

According to UNEP (2011), a green economy is defined as 'low-carbon, resource efficient, and socially inclusive', whose overall objective is 'improved human well- 
being and social equity, while significantly reducing environmental risks and ecological scarcities'. It aims at 'getting the economy right' by reducing polluting emissions, increasing resource efficiency, preventing the loss of biodiversity and valuing ecosystem services (UNEP, 2014).

The waste from agricultural crops accounts for 23 million tonnes (not considering crop residues such as straw, leaves from sugar beet and residues from food processing), or just below $2 \%$ of total consumption of agricultural crops (Faostat, 2014). In addition, about 110mill. $t$ of vegetal and animal waste are generated from food processing, households and other sectors (Eurostat, 2014). For the total biomass coming from agriculture (thus including various crop residues) we estimate that about 1.5 billion tonnes were used in 2011 , of which $15 \%$ for food, $58 \%$ for feed, $18 \%$ for processing and almost $5 \%$ for energy (bio-fuels, heat and electricity) production.

In the EU, we estimate bio-fuel market at about $€ 15.7$ billion in 2012 . Considering the expected use of bio-fuels in 2020 in the transport sector, we estimate, based on the projections for price developments (Charles et al., 2013), that the bio-fuel market could increase to about $€ 30$ billion in 2020 in the EU. Today, bio-fuels are produced largely from food-crops (sugar and starch crops for bio-ethanol and oil crops for biodiesel). A recent European Council decision limited the use of conventional bio-fuels to $7 \%$ of the energy use in transport for 2020 (European Council, 2014); the rest should come from 2 nd generation lingo-cellulosic bio-fuels. In the EU, bio-ethanol is produced from wheat (3.9 mill. t), maize (4.1 mill. t), sugar beet (12.1 mill. t), barley ( 0.4 mill. $t$ ) and rye $(0.4$ mill. $\mathrm{t})$. The bio-ethanol production capacity increased to about 8.5 billion liters per year in 2012, with an actual annual production of about 4.8 billion liters (2.4 Mtoe) or $57 \%$ of the total capacity. Biodiesel is the main bio-fuel used in the EU in transport, being produced from rapeseed (15.3 mill. $\mathrm{t}$ ), soybean (3.5 mill. t), imported palm oil, recycled vegetable oil and animal fat. The biodiesel production capacity increased to about 26.3 billion liters, with an annual production of about 10.5 billion liters (8.3 Mtoe) or $40 \%$ of the total capacity (EC, 2014q, USDA, 2013). A significant share of the feedstock for domestically produced biodiesel (rapeseed, soybean) came from import together with vegetable oil (mainly palm oil) is also used. Due to the cap on food cropbased bio-fuels, a further expansion of first generation bio-fuels is not expected while lingo-cellulosic bio-fuels have not yet achieved commercial maturity.

Increase of world energy demands is in connection with world population grow. According to IIASA model it is predicted that the world energy consumption by the year 2030 will be 306,6 $1012 \mathrm{kWh}$. Development of energy sector is the basis for development of society and demand for different sources of energy is constant and very urgent. Energy strategy of EU "20-20-20" has a long term goal of high energy production with low emission of glasshouse gases. Within this strategy EU countries have to reduce glasshouse gases emission for $20 \%$, raise energy efficiency for $20 \%$ and, $20 \%$ of energy consumption should be from renewable resources. Biomass from agriculture is one of the renewable energy resources that is not enough exploited (Kis et al., 2011). 
The harvesting residues are suitable for composting because they contain a higher percentage of nitrogen compounds. These secondary products can be used as mulch, then for the production of compost and earthworms, or distributed on the field immediately before basic tillage is performed (Collins and Moore, 1995; Glamočlija et al. 2015). More recently, they are increasingly serving as feedstock for bio-fuel production.

Biomass is the most commonly used renewable energy source in the United States. It is a naturally occurring, widely spread carbon resource and a logical choice of raw material for the production of a broad range of substitutes of fossil fuel. Bio-fuels are energy sources derived from biological materials. They can be solid, liquid, or gaseous and all three forms of energy are sustainable and renewable because they are produced from plants and animals. More than half of the fossil fuels people uses are burned in vehicles and to reduce the usage of fossil fuels, companies have started manufacturing vehicles that run on bio-fuels. Many bio-fuels are used in place of gasoline and diesel to run current technology. Unlike fossil fuels, bio-fuels are renewable energy sources that could last indefinitely. There are five main types of bio-fuel: methanol, biodiesel, butanol, ethanol, and bio-oil (Khillar, 2019; Rakaščan et al., 2019a; 2019b). Bio-fuels, on the other hand, are energy sources derived from biological materials, which separate them from other non-fossil fuel energy sources such as wind and wave energy.

In the study attempts to analyze soybean production and possibility obtaining biogas from soybean biomass, in order to obtain energy (renewable) inputs into the profit function and realization of circular economy.

\section{Material and methods used}

Production parameters of soybean in period 2013-2017 are analyzed in this paper. Data on soybean production are taken from the FAO website 2019. At the second part of the research, in 2015-2019. period, the three-year trials were performed by a random block system in three repetitions with the size of the basic plots of $10 \mathrm{~m}^{2}$ on the site Dolovo (N $44^{\circ} 54^{\prime}$ ', E 2052', 110 a.1.s.), Pancevo, South Banat, Serbia. The experiments were carried out on chernozem type soil. The subject of the study was the soybean variety - Favorit (Variety selected at the Institute of Field and Vegetable Crops, Novi $\mathrm{Sad})$. Soybean productivity parameters were examined: plant height, biomass yield and biogas yield. Standard agricultural technology for soybean cultivation has been applied. Samples from mowed biomass were taken to analyze plant height and biomass yield. The biogas yield was determined by soybean silage analysis in the laboratory of the Technical Faculty in Novi Sad and converted to cubic per tonnes. The technology for producing biogas from soybean biomass was carried out in the biodigestor. First, biomass is milling and then insert into the biodigestor where fermentation and biogas production is carried out. Company - Biogas Energy, since its inception, has been involved in exploring the possibilities of improving the supplying of biomass for its needs in an environmentally, economically and energy-sustainable manner. 
Soybean biomass can be used to produce briquettes and pellets, solid fuels suitable for use in smaller boiler plants, for example for heating residential buildings. It can also be used to produce liquid biofuels (ethanol) because it has high amounts of carbohydrates. The technological process of processing into ethanol is carried out in stages. In the first phase, the biomass is chopped and treated with sodium hydroxide to break down the lignin, then, it is hydrolyzing by ferments that break down the complex sugars to hexoses. During the fermentation process, the hexose sugars are converted into ethyl alcohol by the glucoamylase ferment, releasing carbon dioxide $\left(\mathrm{C}_{6} \mathrm{H}_{12} \mathrm{O}_{6} \rightarrow 2 \mathrm{C}_{2} \mathrm{H}_{5} \mathrm{OH}+2 \mathrm{CO}_{2}\right)$. In the distillation process, ethanol is separated from other by-products. Approximately $2 \mathrm{~kg}$ of glucose is required to obtain $1 \mathrm{~kg}$ of ethanol (Richards et al., 1994).

\section{Data analysis}

The experimental data obtained were analyzed by using descriptive and analytical statistics with the statistical package STATISTICA 12 for Windows (StatSoft). Testing the significance of the differences between the calculated mean values of the examined factors (years) was done by using a one-factor model of variance analysis. The defined variance analysis model with one variability factor is presented by a linear model of shape (Mihailović, 2005):

$$
Y_{i j}=\mu+\alpha_{i}+\varepsilon_{j}, \quad \mathrm{i}=1,2, \ldots, \mathrm{k} ; \quad \mathrm{j}=1,2, \ldots, \mathrm{n} .
$$

as the result of sum of three additive components: arithmetic means of the jointly set,

$$
\mu=\frac{1}{k} \sum_{i=1}^{n} \mu_{i}
$$

All significance ratings were derived from the F-test and LSD test for a significance level of $5 \%$ and $1 \%$. The relative dependence of the tested parameters for soybean was determined by the method of correlation analysis (Pearson's correlation coefficients), and the obtained coefficients tested by t-test for significance level of $5 \%$ and $1 \%$. A coefficient of variation was applied to calculate the degree of variation. The coefficient of variation $(\mathrm{Cv})$ is a relative measure of variability, and is used to estimate the variability of a statistical series, by comparing standard deviation and arithmetic mean. It is expressed as a percentage, by the formula: $\mathrm{CV}=\mathrm{b} \cdot 100 / \bar{X}$

The data on the Quantity and distribution of precipitation in the area of Pančevo, Serbia, 2015-2019 are shown, graph. 2. The all results obtained are presented in tables and graphs.

\section{Meteorological data for Pančevo, Serbia}

Serbia belongs to climatic area in which the weather conditions are variable, unstable and unpredictable, primarily precipitation, both by quantity and by schedule (Popović, 2010; Popović et al., 2015; 2016; Maksimović et al., 2018). Almost all soybean production is under natural water regime, so yields depend to a large extent on the amount and http://ea.bg.ac.rs 
distribution of rainfall during the growing season (Bošnjak, 2008; Glamočlija et al., 2015). Soybeans are very sensitive to summer droughts, so grain yield and quality vary significantly by year, making this production very unsafe (Glamočlija et al. 2015; 2019).

The average multi-year temperature in Dolovo was $19.9^{\circ} \mathrm{C}$ and the total precipitation was $369.7 \mathrm{~mm}$. In first year, 2015, the average temperature was $20.1^{\circ} \mathrm{C}$, in second $19.4^{\circ} \mathrm{C}$, in third $18.6^{\circ} \mathrm{C}$, fourth year $18.7^{\circ} \mathrm{C}$, and in fifth year $18.7^{\circ} \mathrm{C}(2019)$ and total precipitation were $427.1 \mathrm{~mm}, 493.9 \mathrm{~mm}, 437.5 \mathrm{~mm}, 397.1 \mathrm{~mm}$ and $324.3 \mathrm{~mm}$, per year. In 2019, precipitation was $45.4 \mathrm{~mm}$ lower than the perennial average, while in the first four years, precipitation was higher by $57.4 \mathrm{~mm}, 124.2 \mathrm{~mm}, 67.8 \mathrm{~mm}$ and $27.4 \mathrm{~mm}$, Figure 1a. Climate change and the regime of soil waters and their interrelationships, which are highly variable and complex, define the success of crop production, since much of our agricultural production is located in areas with occasional droughts (Šimunić et al., 2014; Popović et al., 2019).

\section{Results and Discussion}

\section{Analysis of soybean production}

After the introduction of the preliminary reviews, the authors presented the results of the research for the research period 2013-2017. The average area under soybean in the World in tested period was 118.97 mill. ha, yield was $2.67 \mathrm{t} \mathrm{ha}^{-1}$. World's current average of soybean production is $319,017,790$ tons, Table 1.

The variability of the examined parameters, average area and grain yield in the world, measured by the coefficient of variation, ranged from $4.15 \%<\mathrm{CV}<5.16 \%$ and recorded a growth trend at the rate of $2.52 \%$ and $3.32 \%$, Table 1 .

The average area under soybean in the Republic of Serbia, in period 2013-2017, was 176,577 ha and varied 159,749 (2013) to 201,712 ha (2017). The average grain yield of soybean in Republic of Serbia was $2.78 \mathrm{t} \mathrm{ha}^{-1}$ and varied $2.29 \mathrm{t} \mathrm{ha}^{-1}$ (2017) to 3.54 $\mathrm{t} \mathrm{ha}^{-1}$ (2014) (Table 1). The variability of the examined parameters, average area and grain yield in Republic of Serbia, measured by the coefficient of variation, ranged from $11.03 \%<\mathrm{Cv}<19.97 \%$. Soybean areas in Serbia show an growth trend of $6.55 \%$. The average yields were higher, compared to World yield, by $0.11 \mathrm{t}$. World's average yield has stability, $\mathrm{Cv}=5.16 \%$. Serbia's average soybean production was 480,620 tons and varied 358,214 t (2013) to 576,446 t (2015), Tab.1.

Table 1. Soybean production in Words and in the Republic of Serbia, 2013-2017.

\begin{tabular}{|l|c|c|c|c|c|}
\hline \multicolumn{1}{|c|}{ Parameter } & Average value & Min & Max & $\begin{array}{c}\text { Rate of } \\
\text { change, } \%\end{array}$ & Cv, $\%$ \\
\hline Area, ha & $118,969,192$ & $111,018,797$ & $123,551,146$ & 2.52 & 4.15 \\
\hline Yield, t ha $^{-1}$ & 2.67 & 2.49 & 2.85 & 3.32 & 5.16 \\
\hline Production, $\mathrm{t}$ & $319,017,790$ & $277,533,908$ & $352,643,548$ & 5.87 & 9.01 \\
\hline
\end{tabular}




\begin{tabular}{|l|c|c|c|c|c|}
\hline \multicolumn{1}{|c|}{ Parameter } & Average value & Min & Max & $\begin{array}{c}\text { Rate of } \\
\text { change, } \%\end{array}$ & Cv, \% \\
\hline \multicolumn{7}{|c|}{ Trade - Crops and livestock products in word } \\
\hline Export, $\mathrm{t}$ & $128,804,999$ & $106,168,848$ & $151,838,168$ & 8.93 & 13.50 \\
\hline Import, $\mathrm{t}$ & $126,531,131$ & $103,016,317$ & $148,277,947$ & 9.12 & 13.74 \\
\hline Difference, $\mathrm{t}$ & 2.273 .868 & - & - & - & - \\
\hline \multicolumn{7}{|c|}{ Soybean production in the Republic of Serbia } \\
\hline Area, ha & 176,577 & 159,724 & 201,712 & 6.55 & 11.03 \\
\hline Yield, $\mathrm{t}$ ha ${ }^{-1}$ & 2.78 & 2.29 & 3.54 & -2.01 & 19.97 \\
\hline Production, $\mathrm{t}$ & 480,620 & 358,214 & 576,446 & 3.43 & 17.77 \\
\hline \multicolumn{7}{|c|}{ Trade - Crops and livestock products in the Republic of Serbia } \\
\hline Export, t & 46,261 & 16,946 & 135,843 & 28.51 & 86.46 \\
\hline Import, t & 84,115 & 11,723 & 97,335 & 65.64 & 69.03 \\
\hline Difference, $\mathrm{t}$ & $-46,177$ & - & - & - & - \\
\hline
\end{tabular}

Source: FAO 2019, available 11.12.2019; Authors' calculations

The average Export under soybean in the World in 2013-2017 was 128,804,999 $t$ and the average Import of soybean was 126,531,131 t (Tab. 1). Thus, difference of Export and Import of soybean grain was 2,273,868 t, Table 1 .

The average Export of soybean from the Rep. of Serbia in 2013-2017 was 46,261 t. The average Import of soybean in Republic of Serbia was 84,115 t. Thus, Serbia's difference of Export and Import was $-46,117 \mathrm{t}$ of soybean grain, Table 1.

Serbia has excellent conditions for soybeans production (Terzic et al., 2017; 2018). Soybeans in the world and in Serbia, in recent years, have recorded a permanent tendency of area growth (Popovic, 2010). The average area under soybean in the world was 121.53 million ha, yield was $2.76 \mathrm{t} \mathrm{ha}^{-1}$ and production 334.89 million $\mathrm{t}$. The largest areas in the world were in the Americas, followed by Asia, Europe and Africa. The America is the leading continent in soybean producing and it provides $87.1 \%$ of global soybean production (Terzic et al., 2018; Popović et al., 2020). Grain yield significantly depends on the water supply of the plants, especially in the critical stages of plant growth (Glamočlija et al., 2019).

\section{Productivity parameters of soybean variety - Favorit in Pančevo, Serbia}

The average soybean plant height for variety Favorit in tested period, 2015-2019, was $96 \mathrm{~cm}$. Year had a statistically significant effect on the values of the parameter tested. The most favourable years for plant height were 2018 and $2019(101 \mathrm{~cm})$ while the most unfavourable year was 2015 (87 cm). In 2018 and 2019 the values were statistically significantly higher than in 2015, Tables 2, Figure 1b. Variability of examined parameter, measured by the coefficient of variation, averaged $5.94 \%$ with the rate of change $3.13 \%$. Weather variations significantly affect plant height as cited by Shamsi and Kobraee (2011); De Lucai and Hungría (2014). 
Table 2. Productivity parameters of soybean varietyFavorit, Pančevo, R.of Serbia, 2015-2019.

\begin{tabular}{|l|c|c|c|c|c|}
\hline \multicolumn{1}{|c|}{ Parameter } & $\begin{array}{c}\text { Average } \\
\text { value }\end{array}$ & Min & Max & $\begin{array}{c}\text { Rate of change, } \\
\%\end{array}$ & $\begin{array}{c}\mathrm{Cv} \\
\%\end{array}$ \\
\hline Plant height, $\mathrm{cm}$ & 96 & 87 & 101 & 3.13 & 5.94 \\
\hline Biomass yield, $\mathrm{t} \mathrm{ha}^{-1}$ & 4.59 & 3.99 & 4.92 & 3.93 & 8.36 \\
\hline Biogas yield, $\mathrm{m}^{3} \mathrm{ha}^{-1}$ & 368 & 345 & 382 & 5.87 & 9.01 \\
\hline Source:
\end{tabular}

Source: Biogas Energy; Authors' calculations

Figure 1. Average temperature, ${ }^{\circ} \mathrm{C}$, and total precipitation, $\mathrm{mm}$, in soybean growing period, Pančevo, Serbia (a), Effect of precipitation, $\mathrm{mm}$, on soybean productivity parameters: b) plant height, cm, c) biomass yield, $\mathrm{kg} \mathrm{ha}^{-1}$, and d) biogas yield, $\mathrm{m}^{3} \mathrm{~kg}^{-1} ; 2015-2019$
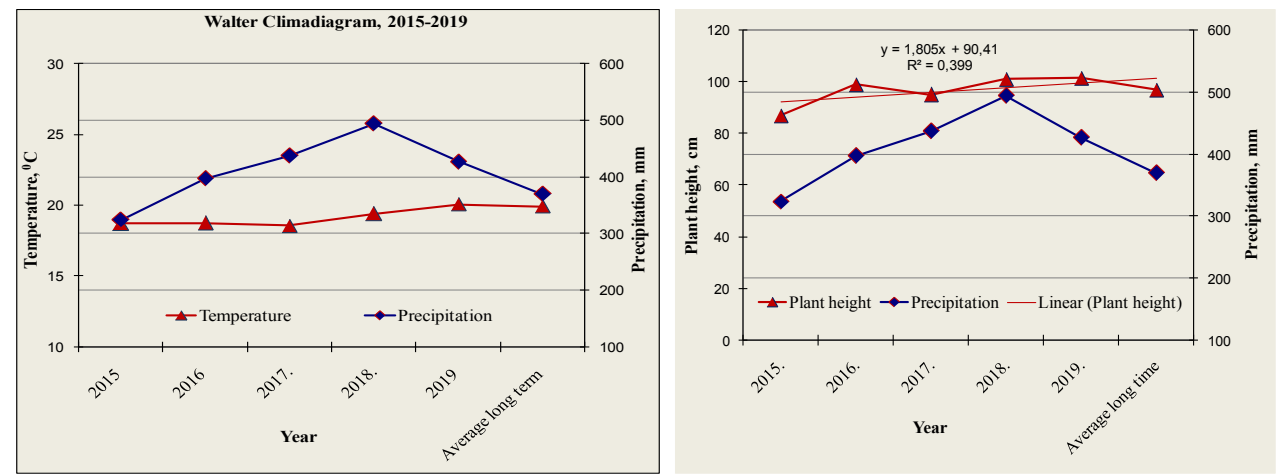

a.

b.
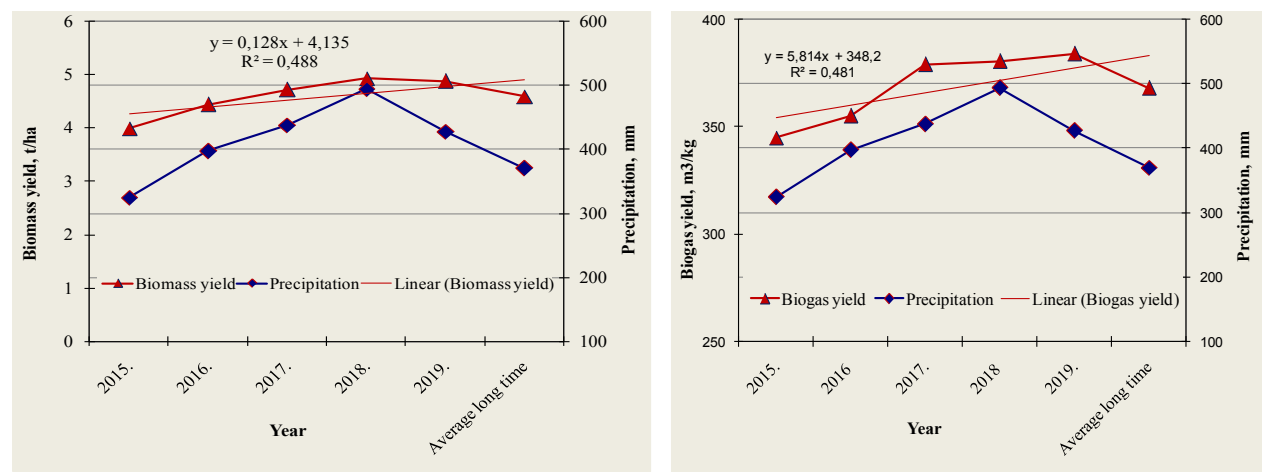

c.

d.

Source: Author's calculations

The average soybean biomass yield of variety - Favorit, for tested five years, was 4.59 $\mathrm{t} \mathrm{ha}^{-1}$. Average biomass yield varied from $3.99 \mathrm{t} \mathrm{ha}^{-1}$ (2015) to $4.92 \mathrm{t} \mathrm{ha}^{-1}$ (2018), Table 2 , Figure 1c. The variability of the investigated parameters, plant height and biomass yield, ranged from $5.94 \%<\mathrm{Cv}<8.36 \%$. 
The average biogas yield of soybean variety - Favorit, for tested five years, was $368 \mathrm{~m}^{3}$ $\mathrm{ha}^{-1}$. Average biogas yield varied from $345 \mathrm{~m}^{3} \mathrm{ha}^{-1}$ (2015) to $382 \mathrm{~m}^{3} \mathrm{ha}^{-1}$ (2019), Table 2 , Figure $1 \mathrm{~d}$. The variability of the investigated parameter, measured by the coefficient of variation, averaged $9.01 \%$, Table 2 .

Therefore, the areas vary significantly from year to year, from 160,000 ha to 230,000 ha. Yield variations by years are even more pronounced. Success in dry farming of soybean depends on the application of agro-technical measures adapted to agro-ecological and soil conditions. One of the measures is the selection of the variety that is best adapted to local environmental conditions (Popović et al. 2013a, 2020).

Soybean harvest residues are increasingly used for energy purposes today. According to numerous authors, straw will represent the most important non-food crop material due to its chemical composition and relatively simple biofuel production process (Bulgariu and Bulgariu, 2018).

Scientists in countries with large areas under soybeans over the past decades were working to improve methods of producing bio fuels from soybean plant material. Commercial production should be economically and environmentally friendly so that renewable fuels could be an adequate substitute for fossil fuels. This would reduce the use of liquid and solid fuels from oil and coal, which by combustion emit significantly higher amounts of gases that have adverse effects on the ecosystem (greenhouse effect). The importance of using bio-fuels also lies in the fact that many countries do not have large reserves of fossil fuels for their own needs and are forced to procure them in an unstable market. Soybean straw is a very accepted solid fuel in our country as an inexpensive form of energy and without significant environmental impact. It is most commonly used for combustion in boiler plants, as baled biomass. Straw combustion systems are so sophisticated today that the burning process is as simple as using solid and liquid fossil fuels. In naturally dry straw, it has about $90 \%$ combustible substance, 7-8\% water and 2.5-3\% mineral salts (ash). By combustion of soybean straw in boiler plants with lattice firebox for bale, it gets more than $17 \mathrm{~kJ}$ of energy per kilogram of biomass, or from one hectare ( $80 \%$ of the collected straw) about $60,000 \mathrm{MJ}$ (Janković et al., 2019). This value corresponds to $1,100 \mathrm{~kg}$ of diesel fuel, or $1,300 \mathrm{~N} \mathrm{~m}^{3}$ of natural gas. Facilities plants using briquetted soybean straw (and other crops) have been accepted by both large industrial plants and small businesses and households.

\section{Correlations with tested parameters}

The biomass yield was in positive and statistically very significant dependence on the biogas yield $\left(0.94^{* *}\right)$ and on the plant height $\left(0.80^{* *}\right)$ and the negative very significant dependence with the temperature $(0.93 * *)$, Table 3, Graph. 2. 
Table 3. Correlations of tested parameters

\begin{tabular}{|c|c|c|c|c|c|}
\hline Parameter & Plant height & Biomass yield & Biogas yield & Temperature & Precipitation \\
\hline Plant height & 1.00 & $0.80^{* *}$ & $0.65^{*}$ & $-0.65^{*}$ & $-0.27^{\text {ns }}$ \\
\hline Biomass yield & $0.80^{* *}$ & 1.00 & $0.94^{* *}$ & $-0.93^{* *}$ & $-0.49^{\text {ns }}$ \\
\hline Biogas yield & $0.65^{*}$ & $0.94^{* *}$ & 1.00 & $-0.95^{* *}$ & $-0.60^{*}$ \\
\hline
\end{tabular}

Source: Author's calculations; ${ }^{\text {ns }}$ - non significant; * and ** significant at 0.5 and 0.1

The biogas yield was in positive statistically significant dependence on the plant height $\left(0.65^{*}\right)$ and in the negative very significant dependence with the temperature $\left(0.95^{* *}\right)$ and significant dependence with precipitation $(0.60 *)$, Table 3.

Figure 2. 3D Surface plot for plant height, biogas and biomass yield, 2015-2019.

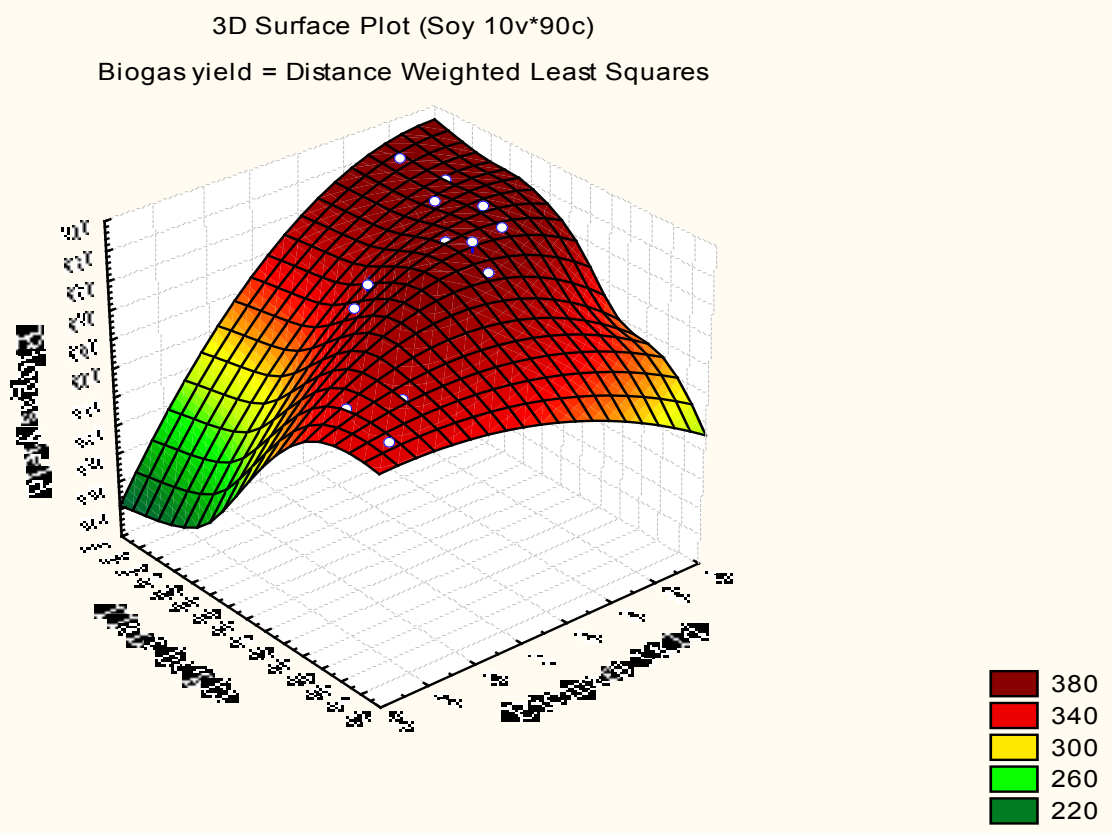

Source: Author's calculations

After harvesting soybean grain, over $5 \mathrm{t} \mathrm{ha}^{-1}$ of vegetative biomass of stalk and leaf residues remains, twice the average yield of the main product, the grain. Thanks to the development of new technologies for the treatment of bio-waste into energy, the rate of increase in the use of alternative fuels is increasing significantly. Biomass soybean is a very accepted solid fuel in our country, as a cheap form of energy and without significant environmental impact. It is most commonly used for combustion in boiler plants, as baled biomass. In naturally dry straw, there is about $90 \%$ combustible substance, $7-8 \%$ water and 2.5-3\% mineral salts (ash). Combustion of soybean straw in boiler plants with lattice firebox for bales, yields more than $17 \mathrm{~kJ}$ of energy per 
kilogram of biomass, or from one hectare ( $80 \%$ of the collected straw) about 60.000 MJ. This value corresponds to $1.100 \mathrm{~kg}$ of diesel fuel, or $1.300 \mathrm{~N} \mathrm{~m}^{3}$ of natural gas.

Facilities plants using briquetted soybean straw (and other crops) have been accepted by both large industrial plants and small businesses and households.

Soybean varieties with their characteristics justify the sowing and can be used as a raw material in bio-fuels production and efficient fertilizer (Kis et al., 2011). In order to make the bio-sorption process more suitable for industrial applications, biomass of soy waste (a low-cost waste, resulted after oil extraction) was functionalized with industrial sulphur based chelating agent, which is a precipitation agent used in industrial wastewater treatment, and used for the removal of some heavy metals from aqueous solution. The exhausted bio-sorbent can be easily regenerated with $0.1 \mu \mathrm{M}$ $\mathrm{HNO}_{3}$ solution, and the regenerated functionalized soy waste biomass (SCA-SWB) biosorbent can be used in at least five bio-sorption/desorption cycles. The tests performed with real wastewater samples and some economic considerations indicate the potential of SCA-SWB as suitable alternative bio-sorbent for the removal of heavy metal ions with industrial applications.

Biomass is a renewable energy source derived from all plants and materials derived from plants, including forestry residues, pulp and paper mills waste, animal manure, urban wood waste and so on (Khillar, 2019).

Commercial production should be economically and environmentally friendly so that renewable fuels could be an adequate replacement for fossil fuels.

\section{Conclusion}

According to the obtained results of research, the following conclusions were made:

Soybean production in the world and in Serbia has a steady upward trend, primarily due to increased areas and yields. World's current average soybean production is 319.017 .790 tons. Serbia has excellent conditions for soybeans production. The average area under soybean in the Serbia, varied from 159.724 ha to 201712 ha. The average grain yield of soybean of Serbia varied 2.41 to $3.54 \mathrm{t} \mathrm{ha}^{-1}$. The variability of the examined parameters, surface area and grain yield in Serbia, measured by the coefficient of variation, ranged from $11.03 \%<\mathrm{Cv}<19.97 \%$

The average biogas yield of soybean variety - Favorit, for tested five years, was 368 $\mathrm{m}^{3} \mathrm{ha}^{-1}$. Average biogas yield varied from $345 \mathrm{~m}^{3} \mathrm{ha}^{-1}$ (2015) to $382 \mathrm{~m}^{3} \mathrm{ha}^{-1}$ (2019). The variability of the tested parameter, measured by the coefficient of variation, averaged $9.01 \%$. The biogas yield was in positive statistically significant dependence on the plant height $\left(0.65^{*}\right)$.

Soybean varieties with their characteristics justify the sowing and can be used as a raw material in biofuels production. 


\section{Acknowledgement}

Research was supported by the Ministry of Education, Science and Technological Development of the Republic of Serbia (Projects: TR 31022; 2011-2020) and bilateral project (Montenegro-Serbia; 2019-2020): Alternative cereals and oil crops as a source of healthcare food and an important raw material for the production of biofuel.

\section{Conflict of interests}

The authors declare no conflict of interest.

\section{References}

1. Bojović, R., Popović, V., Ikanović, J., Živanović, Lj., Rakaščan, N., Popović, S., Ugrenović, V., \& Simić, D. (2019). Morphological characterization of sweet sorghum genotypes acrossen environments. The J.of Anim. Plant Sci. 29(3), 721729.

2. Bošnjak, Đ. (2008). Navodnjavanje soje u redovnoj, drugoj i postrnoj setvi. Monografija. Institut za ratarstvo i povrtarstvo, Novi Sad, 323-249. [in English: Irrigation of soybeans in regular, second and post sowing. Soybean, Monograph. Institute of Field and Vegetable Crops, Novi Sad, 323-249.]

3. Bulgariu, L., \& Bulgariu, D. (2018). Functionalized soy waste biomass - A novel environmental-friendly biosorbent for the removal of heavy metals from aqueous solution. Journal of Cleaner Production. 197 (1): 875-885. DOI: 10.1016/j. jclepro.2018.06.261

4. Collins, M., \& Moore, K. J. (1995). Postharvest processing of forages. In: Barnes, R.F., Miller, D.A., \& Nelson, C.J. (eds). Forage: The Science of Grassland Agriculture, Ames, IA, Iowa, 147-161.

5. De LucaI, M. J., \& Hungría, M. (2014). Plant densities and modulation of symbiotic nitrogen fixation in soybean. Scientia Agricola, 71(3): 181-187. https:// doi.org/10.1590/S0103-90162014000300002.

6. European Council, (2014). Conclusions on 2030 Climate and Energy Policy Framework,EUCO169/14, http://www.consilium.europa.eu/uedocs/cms_data/ docs/pressdata/en/ec/145397.pdf, downloaded, 11.12.2019.

7. Eurostat(2014).http://epp.eurostat.ec.europa.eu/portal/page/portal/statistics/ search database

8. FAO (2014). Faostat, 2014. http://faostat3.fao.org/home/E, downl., 11.12.2019.

9. FAO (2019). Faostat.fao.org/; Faostat | C FAO Statistics Division 2019| 11.12 .2019

10. Glamočlija, Đ., Janković, S., Popović, M.V., Kuzevski, J., Filipović, V., \& Ugrenović, V. (2015). Alternativne ratarske biljke u organskom i konvencionalnom sistemu gajenja. Monografija. Beograd. 1-355. [in English: Alternatively crop plants in conventional and organic growing systems. Monograph. Belgrade, ISBN 978-86-81689-32-5; 1-355.] 
11. Glamočlija, Đ., Ugrenović, V., Đurić, N., Popović, V., Mladenović-Glamočlija, M., \& Filipović, V. (2019): Soybean genotype productivity in divergent years on chernozem. Agricultural production. Sustainable agricultural production. The role of agriculture in environmental protection, Biofarming, Bačka Topola. 2: 135-142.

12. Janković, S., Glamočlija, Đ., \& Prodanović, S. (2017): Energy crops. Monograph, Belgrade.

13. Janković, S., Glamočlija, Đ., Ikanović, J., \& Rakić, S. (2019). Secondary crop products. Monograph, Belgrade. ISBN 978-86-81689-41-7, 1-385.

14. Kis, D., Maric, S., Juric, T., Guberac, V., \& Loncaric, Z. (2011). Soybean biomass as fuel and fertilizer. 22nd International Scientific-Expert Conference of Agriculture and Food Industry, Sarajevo, 323-325.

15. Khillar, S. (2019). Difference Between Biofuel and Biomass. DifferenceBetween. net. June 24, 2019. http:/www.differencebetween.net/science/difference-betweenbiofuel-and-biomass/.

16. Kolarić, Lj., Živanović, Lj., Popović, V., \& Ikanović, J. (2014). Influence of interrow spacing and cultivar on the yield components of soybean [Glycine max (L.) Merr.]. Agriculture and Forestry, Podgorica, 60 (2), 167-176. www.agricultforest. ac.me

17. Lakić, Ž., Glamočlija, Đ., Kondić, D., Popović, V., \& Pavlović, S. (2018). Krmne biljke i žita u funkciji zaštite zemljišta od degradacije. Banja Luka, 1-405. [In English: Forage plants and cereals for the protection of soil from degradation. Monograph. Banja Luka.]

18. Maksimović, L., Popović, V., \& Stevanović, P. (2018). Water and irrigation requirements of field crops grown in central Vojvodina, Serbia. Agriculture and Forestry, Podgorica, 64 (1): 133-144. DOI: 10.17707/AgricultForest.64.1.16

19. Mihailović, B. (2005). Marketing. Book. Podgorica, Montenegro. 1-400.

20. Novaković, S., Vukasović, D., Laban, B.,Ivić, M., Popović, V. \& Popović, S. (2018). Managing agricultural company by using internal control and significance of risk presentation, Economics of Agriculture, 2: 801-812. doi:10.5937/ekoPolj1802801N

21. Popović, V. (2010). Agrotehnički i agroekološki uticaji na proizvodnju semena pšenice, kukuruza i soje. Doktorska disertacija, Univerzitet u Beogradu, Poljoprivredni fakultet Zemun, 1-145. [In English: Influence of agrotechnical and agroecological practices on seed production of wheat, maize and soybean. Doctoral Thesis, University of Belgrade, Faculty of Agriculture, Zemun, In Serbian. 1-145.]

22. Popovic, V., Vidic, M., Jockovic, Dj., Ikanovic, J., Jaksic, S., \& Cvijanović, G. (2012a). Variability and correlations between yield components of soybean [Glycine $\max ($ L.) Merr.]. Genetika, Belgrade, 44(1): 33-45.

23. Popovic, V., Jaksic, S., Glamoclija, Dj., Djekic, V., Grahovac, N., Mickovski Stefanovic, V. (2012b). Variability and correlations between soybean yield and quality components, Romanian Agricultural Research, 29: 131-136. 
24. Popović, V., Glamočlija, Đ., Sikora, V., Đekić, V., Červenski, J, \& Simić, D. (2013a): Genotypic specificity of soybean [Glycine max (L.) Merr.] under conditions of foliar fertilization. Romanian Agricultural Research, 30, 259-270.

25. Popović, V., Malešević, M., Miladinović,J., Marić,V.,\& Živanović, Lj.(2013b). Effect of agroecological factors on variations in yield, protein and oil contents in soybean grain. Romanian Agricultural Research, 30,241-247. DII 2067-5720 RAR 207

26. Popović, V., Miladinović, J., Vučković, S., Dolijanović, Ž., Ikanović, J., Živanović, Lj. \& Kolarić Lj. (2015): Drought - a limiting factor in soybean production; Effect of irrigation on soybean yield-Glycine max. Institute of PKB Agroekonomik,21(1),11-21.

27. Popovic, V., Tatic, M., Sikora, V., Ikanovic, J., Drazic, G., Djukic, V., Mihailovic, B., Filipovic, V., Dozet, G., Jovanovic, Lj., \& Stevanovic, P. (2016). Variability of yield and chemical composition in soybean genotypes grown under different agroecological conditions of Serbia. Romanian Agricultural Research, 33, 29-39. DII 2067-5720 RAR 2016-167

28. Popović, V., Kolarić, Lj., Živanović, Lj., Ikanović, J., Rajičić, V., Dozet, G., \& Stevanović, P. (2018a). Influence of row spacing on NAR-Net Photosynthesis Productivity of Glycine max (L.) Merrill. Agriculture and Forestry, 64 (1): 159169. DOI:10.17707/AgricultForest.64.1.18

29. Popović, S., Đuranović, D., Laban, B., Ivić, M., Jovin, S., Nastić, S., Grublješić, Ž., \& Popović, V. (2018b). Impact of different light intensity on the production of the plant narcissus L. and its financial effects, Economics of Agriculture, 4: 1359-1370. doi:10.5937/ekoPolj1804359P

30. Popović, V., Stevanović, P., Vučković, S., Ikanović, J., Rajičić, V., Bojović, R., \& Jakšić, S. (2019a). Influence of CAN fertilizer and seed inoculation with NS Nitragin on Glycine max plant on pseudogley soil type. Agriculturae Conspectus Scientificus - ACS, Croatia, 84 (2), 162-171.

31. Popović, V., Mihailović, V., Vučković, S., Ikanović, J., Rajičić, V., Terzić, D., Simić, D. (2019b). Prospects of Glycine max Production in the World and in the Republic of Serbia. Chapter 7. Ed. Janjev. I. Book: Serbia: Current Issues and Challenges in the Areas of Natural Resources, Agriculture and Environment. NOVA Science publishers, INC., USA, ISBN: 978-1-53614-897-8, 171-194. 1-391.

32. Popović, S., Popović, V., Vučković, S., Jovović, Z., Rajičić, V., Ikanović, J., \& Bojović, R. (2020): Analisys trends of soybean production in Word. GEA, International GEA, Geo Eco-Eco Agro Conference, 28-31.5.2020, Podgorica, MNO, 2: 20-30.

33. Radović, M., Vitomir, J., Laban B., Jovin, S., Nastić S., Popović, V., Popović, S. $\&$ (2019). Management of joint-stock companies and farms by using fair value of agricultural equipment in financial statements on the example of IMT 533 tractor. Economics of Agriculture, 66 (1): 35-50. DOI: https://doi.org/10.5937/ ekoPolj1901035R. 
34. Rajičić, V., Milivojević, J., Popović ,V., Branković, S., Đurić, N., Perišić, V., \& Terzić, D. (2019). Winter wheat yield and quality depending on the level of nitrogen, phosphorus and potassium fertilization. Agriculture \& Forestry, 65(2): 79-88. DOI:10.17707/AgricultForest.65.2.06

35. Rakaščan, N., Dražić, G., Živanović, Lj., Ikanović, J., Jovović, Z., Lončar, M., Bojović, R., \& Popović, V. (2019a). Effect of genotypes and locations on wheat yield components. Agriculture \& Forestry, 65 (1): 233-242, DOI: 10.17707/ AgricultForest.65.1.23

36. Rakašćan, N., Popović, V., Dražić, G., Ikanović, J., Popović, S., Popović, B., \& Milanović, T. (2019b). Circular economy in function of obtaining the biogas. XXIII International Eco-Conference ${ }^{\circledR} 2019$ and XIII Environmental Protection of Urban and Suburban, Settlements, 25th - 27th September 2019, Novi Sad, Serbia, 320-329.

37. Richards, B. K., Herndon, F. G., Jewell, W. J., Cummings, R. J., \& White, T. E. (1994). In situ methane enrichment in methanogenic energy crop digesters. Biomass and Bioenergy, 6(4), 275-274.

38. Shamsi, K., \& Kobraee, S. (2011). Soybean agronomic responses to plant density. Annals of Biological Research, 2(4), 168-173.

39. Scarlat, N., Dallemand, J.F., Banja, M. (2013). Possible impact of 2020 bioenergy targets on European Union land use. A scenario-based assessment from national renewable energy action plans proposals, Renew.Sustai. Ener.Rev., 18(1), 595-606. DOI: $\underline{10.1016 / \text { j.rser.2012.10.040 }}$

40. Scarlat, N., Dallemand, J-F, Monforti-Ferrario, F., \& Nita, V. (2015). The role of biomass and bioenergy in a future bioeconomy: Policies and facts. Environmental Development, 15, 3-34. DOI: $10.1016 / \mathrm{j}$. envdev.2015.03.006

41. Stevanović, P., Popović, V., Filipović, V., Terzić, D., Rajičić, V., Simić, D., Tatić, M., Tabaković. M. (2017). Uticaj đubrenja na masu nodula i sadržaj azota u nodulama soje (Glycine max (L.) Merr.). Institut PKB Agroekonomik. 23, 1-2, 119-127. [In English: Effect of fertilization on nodule mass and nitrogen content in soybean nodules (Glycine max (L.) Merr.). Institute of PKB Agroekonomik. 23, 1-2, 119127.]

42. Šimunić, I., Spalević, V., Vukelić-Shutoska, M., Šoštarić, J., \& Marković, M. (2014). Impact of soil water shortage on crop yields. Croatian waters. 22, 203-212.

43. Terzić, D., Radović, J., Marković, J., Popović, V., Milenković, J., Vasić, T., \& Filipović, V. (2017): Nov tehničko-tehnološki proces proizvodnje voluminozne stočne hrane združivanjem kukuruza i soje u postrnoj setvi. Tehničko rešenje. 1-30. [In English: A new technical and technological process for the production of voluminous fodder by combining maize and soybean in the second sowing. Technical solution. 1-30. ]

44. Terzić, D., Popović, V., Tatić, M., Vasileva, V., Đekić, V., Ugrenović, V., Popović, S., \& Avdić, P. (2018). Soybean area, yield and production in world. XXII EcoConference ${ }^{\circledR 2018, ~ E c o l o g i c a l ~ M o v e m e n t ~ o f ~ N o v i ~ S a d, ~ 136-145 . ~}$ 
45. Terzić, D., Popović, V., Malić, N, Ikanović, J, Rajičić, V., Popović, S., Lončar, M., \& Lončarević. V. (2019). Effects of long-term fertilization on yield of siderates and organic matter content of soil in the process of recultivation. The J. Anim. Plant Sci. 29(3), 790-795.

46. UNEP, (2011). Towards a Green Economy: Pathways to Sustainable Development and Poverty Eradication, http://www.unep.org/greeneconomy

47. UNEP, (2014). Green Economy Initiative, http://www.unep.org/greeneconomy/.

48. USDA, (2013). EU Biofuels Annual 2013, GAIN Report Number: NL3034:

49. Živanović, Lj., \& Popović, V. (2016). Proizvodnja soje (Glycine max) u svetu i kod nas. XXI Savetovanje o bioteh., Čačak, 21 (23), 129-135. [In English: Production of soybean (Glycine max) in the world and in Serbia.XXI Conference on Biotechnology.]

50. Živanović, Lj., Savić, J., Kolarić, Lj., Ikanović, J., Popović, V., \& Novaković, M. (2017). Uticaj genotipa na prinos zrna pšenice, soje, kukuruza i suncokreta. Časopis Instituta PKB Agroekonomik, Beograd, 23 (1-2), 39-48. [In English: The influence of genotype on wheat, soybean, corn and sunflower grain yield. Journal of Institute of PKB Agroekonomik, Belgrade, 23(1-2), 39-48.] 